\title{
Pharmacological Treatment of Obesity in Children and Adolescents : Present and Future
}

\author{
Lorenzo Iughetti, Mariachiara China, Rossella Berri, and Barbara Predieri \\ Obesity Research Center, Department of Pediatrics, University of Modena and Reggio Emilia, Via del Pozzo 71, 41100 Modena, Italy \\ Correspondence should be addressed to Lorenzo Iughetti, iughetti.lorenzo@unimore.it
}

Received 27 July 2010; Revised 12 October 2010; Accepted 13 October 2010

Academic Editor: A. Halpern

Copyright () 2011 Lorenzo Iughetti et al. This is an open access article distributed under the Creative Commons Attribution License, which permits unrestricted use, distribution, and reproduction in any medium, provided the original work is properly cited.

The prevalence of overweight and obesity is increasing in children and adolescents worldwide raising the question on the approach to this condition because of the potential morbidity, mortality, and economic tolls. Dietetic and behavioral treatments alone have only limited success; consequently, discussion on strategies for treating childhood and adolescent obesity has been promoted. Considering that our knowledge on the physiological systems regulating food intake and body weight is considerably increased, many studies have underlined the scientific and clinical relevance of potential treatments based on management of peripheral or central neuropeptides signals by drugs. In this paper we analyze the data on the currently approved obesity pharmacological treatment suggesting the new potential drugs.

\section{Introduction}

The report from the International Obesity Taskforce (IOTF) on worldwide prevalence rate shows that the pediatric obesity epidemic has spread globally. The worldwide prevalence of overweight in children and adolescents is approximately $10 \%$ with many western countries approaching $30 \%$. In fact, some countries in economic transition have also prevalence rate increase higher than those in the United States (US) [13].

Because of the number of the subjects, obesity is now recognized as a healthcare issue on an epidemic scale in both adult and pediatric populations, but it yet remains an unsolved medical problem [4].

The successful management of obesity is theoretically possible through lifestyle changes including diet modifications [5] and increased physical activity. The literature analysis demonstrated, however, that significant results were obtained only in a limited number of subjects and for a relatively short time period: also the management with psychological involvement let the problem substantially unsolved. These considerations recently promoted an interest in pharmacological interventions and bariatric surgery [4].
The renewed interest for a pharmacological approach depends on the knowledge of physiological systems involved in the control of food intake and body weight that has considerably increased over the past decade. A powerful and complex physiological system, based on both afferent and efferent signals, regulating food intake and energy homeostasis, has been elucidated. This system consists of multiple pathways with redundancy signals that are transmitted by both blood and peripheral nerves, which are integrated in brain centres with subsequent regulation of central neuropeptides which in turn modulate feeding and energy expenditure. Appetite includes different aspects of eating patterns, such as frequency and size of eating, choice of high-fat or low-fat foods, energy density of consumed foods, variety of accepted foods, palatability of diet, and variability in day-to-day intake. Feeding behavior is controlled by a series of short-term hormonal, psychological, and neural signals. All signals act at several central nervous system (CNS) sites, but the pathways converge on the hypothalamus, a central region of feeding regulation, containing numerous peptides and neurotransmitters that influence food intake [6]. CNS also regulates energy homeostasis on the basis of peripheral signals from the gastrointestinal tract (GIT) and adipose tissue. 
TABLE 1: Neurotransmitters influencing appetite.

\begin{tabular}{|c|c|}
\hline $\begin{array}{l}\text { Neurotransmitters that } \\
\text { increase food intake }\end{array}$ & $\begin{array}{l}\text { Neurotransmitters that decrease } \\
\text { food intake }\end{array}$ \\
\hline Agouti-related peptide & $\begin{array}{l}\text { Alpha melanocyte-stimulating } \\
\text { hormone }\end{array}$ \\
\hline Neuropeptide Y & $\begin{array}{l}\text { Bombesin-/gastrin-releasing } \\
\text { peptide }\end{array}$ \\
\hline $\begin{array}{l}\text { Melanin-concentrating } \\
\text { hormone }\end{array}$ & Calcitonin gene-related peptide \\
\hline Orexin & Cholecystokinin \\
\hline Galanin & Corticotrophin-releasing factor \\
\hline Ghrelin & Dopamine \\
\hline Nitric oxide & GABA \\
\hline Noradrenaline & Glucagon \\
\hline \multirow[t]{3}{*}{$\begin{array}{l}\text { Opioids (particularly } \mu \text { and } \kappa \\
\text { agonists) }\end{array}$} & $\begin{array}{l}\text { Glucagon-like peptide } 1 \text { (7-36) } \\
\text { amide }\end{array}$ \\
\hline & Neurotensin \\
\hline & Serotonin \\
\hline
\end{tabular}

In this paper, we summarize the currently approved pharmacological treatment for children and adolescents, and we are going to provide an overview of developing drugs.

\section{Pharmacological Treatment of Obesity}

Current and putative antiobesity drugs share the same fundamental principles as treatment in adults, that is, to decrease caloric intake and increase energy expenditure, miming the effects of some anorectic neuropeptides or contrasting the orectic ones in order to regulate energy balance (Tables 1 and 2).

However, the primary goal of overweight/obesity treatment (i.e., weight reduction or deceleration of weight gain) and the recommended way of intervention are variable and dependent on the child's age and level of overweight, among other considerations. In order to support clinicians in determining the most appropriate form of treatment, pediatric weight management guidelines exist in many countries to promote best practice, but at present many of these recommendations are based on low-grade scientific evidence.

A recent guideline suggests considering pharmacotherapy in

(1) obese children only after failure of a formal program of intensive lifestyle modification;

(2) overweight children only if severe comorbidities persist despite intensive lifestyle modification, particularly in children with a strong family history for type 2 diabetes or premature cardiovascular disease. Pharmacotherapy should be provided only by clinicians who are experienced in the use of antiobesity agents and aware of the potential for adverse reactions [7].

Up to now, only three drugs have been reported to reduce weight and/or body mass index (BMI) in adolescents:
(1) sibutramine, a neurotransmitter reuptake inhibitor which enhances satiety by inhibiting the reuptake of serotonin, norepinephrine, and dopamine, (2) orlistat, a pancreatic lipase inhibitor which reduces fat absorption, and (3) metformin, an antihyperglycemic and insulin-sensitizing agent (Table 3).

At present, there are only few drugs approved by the Food and Drug Administration (FDA) for the treatment of adult obesity. The most important ones are sibutramine and orlistat. The FDA in the US approved the latter drug in 2003, and it has recently been approved by the European Union for the treatment of adolescents.

\section{Current Available Drugs}

\subsection{Drugs Affecting Peripheral Mechanisms}

3.1.1. Orlistat. Orlistat, approved since 1998, is an inhibitor of pancreatic lipase reducing dietary fat absorption. The compound is a partially hydrated derivative of an endogenous lipstatin produced by Streptomyces toxytricini [19].

Orlistat binds irreversibly to the active sites of lipase through covalent binding. Approximately one-third of triglyceride intakes does not undergo digestion and is not absorbed by small intestine, crossing the GI tract and being eliminated. Because of low systemic absorption and first-pass metabolism, the bioavailability of orlistat is $<1 \%$; most of the drug being excreted remains unchanged with stools [20].

In adults, orlistat has a good safety profile, is generally well tolerated, has minimal systemic absorption, and determines clinically meaningful and sustained decreases in weight and BMI when combined with a mildly hypocaloric diet and exercise. It is approved for weight management in overweight and obese adults in more than 120 countries, and to date more than 22 million patients have received this drug. Based on clinical and safety characteristics in adult populations, it was considered a logical choice for study in the obese pediatric population because of the nonsystemic mechanism of action.

FDA in December 2003 approved orlistat use in adolescents aged 12 to 18 years old with a BMI $\left(\mathrm{kg} / \mathrm{m}^{2}\right)>2$ units above the reference value at the 95th percentile for age and gender. This conclusion was based on the results of a oneyear study evaluating 539 American adolescents submitted to a hypo-caloric diet plus exercise and behavioral therapy and that were randomized to orlistat versus placebo: a significant decrease in BMI was shown in the orlistat group (0.55 versus $0.31 \mathrm{~kg} / \mathrm{m}^{2}$ for placebo; $P<.01$ ) [8]. Moreover, body composition analysis showed that orlistat did not affect the normal increase in lean body mass physiologically observed in adolescents, and the weight difference between the placebo and orlistat groups was due to a difference in fat mass. The use of orlistat for 1 year in this adolescent population did not raise major safety issues although GIT adverse events, such as fatty or oily stools, oily spotting, increased defecation, cramps, and abdominal pain, were more common in the orlistat group.

Chanoine et al. also measured estradiol levels, cardiovascular effects, gallbladder structure, renal structure, bone 
TABLE 2: Selected GI, pancreatic, and adipose tissue peptides that regulate food intake.

\begin{tabular}{lccc}
\hline Peptide & Main site of synthesis & Receptors mediating feeding effects & Effect on food intake \\
\hline CCK & Proximal intestinal I cells & CCK1R & inhibition \\
GLP-1 & Distal intestinal L cells & GLP-1R & inhibition \\
Oxyntomodulin & Distal intestinal L cells & GLP-1R and others & inhibition \\
PYY & Distal intestinal L cells & Y2R & inhibition \\
Enterostatin & Exocrine pancreas & F1-ATPase beta subunit & inhibition \\
APO AIV & Intestinal epithelial cells & Unknown & inhibition \\
PP & Pancreatic F cells & Y4R, Y5R & inhibition \\
Amylin & Pancreatic beta cells & CTRS, RAMPS & inhibition \\
GRP and NMB & Gastric myenteric neurons & GRPR & inhibition \\
Gastric leptin & Gastric chief and P cells & Leptin receptor & inhibition \\
Ghrelin & Gastric x/a-like cells & Ghrelin receptor & stimulation \\
Insulin & Pancreatic beta cells & Insulin receptor & inhibition \\
Leptin & Adipocytes & Leptin receptor & inhibition \\
Adiponectin & Adipocytes & Adiponectin receptor & inhibition \\
\hline
\end{tabular}

CTRs: calcitonin receptors; RAMPs: receptor activity-modifying proteins; GRP: gastrin-releasing peptide; NMB: neuromedin B; GRPR: GRP receptor.

mineral content/density, and other non-GIT adverse events [8]. Girls in the orlistat group had a statistically significant decrease in estradiol concentrations compared with a slight increase shown in the placebo intervention. Ten participants in the orlistat group and one participant in the placebo group developed abnormalities during the study that were detected on electrocardiograms; none of these was believed to be related to the medication based on review by an independent cardiologist. No other adverse cardiovascular effects were found. At the end of the study, six participants in the orlistat intervention (compared with one participant in the placebo intervention) were found to have asymptomatic gallstones not seen at baseline; five of these patients had lost large amounts of weight $(8.2-29.4 \mathrm{~kg})$, and two were siblings. Another patient had multiple gallstones on ultrasound at day 167 after a $15.8 \mathrm{~kg}$ weight loss and had a subsequent cholecystectomy. Ultrasound also identified two additional new renal abnormalities in the orlistat intervention group (mild left hydronephrosis and $6 \mathrm{~mm}$ echogenic focus without evidence of renal calculus). There were no differences in bone mineral content/density between the two interventions.

Most other non-GIT adverse events were also more prevalent in the orlistat group compared with the placebo group, but the difference between groups was less pronounced than for GIT adverse events; the most common adverse events in this category were headache, upper respiratory tract infection, and nasopharyngitis [8].

As in adults, $120 \mathrm{mg}$ three times daily prescribed with meals are usually necessary to produce a significant effect. Coprescription of a daily multivitamin $(\mathrm{A}, \mathrm{D}, \mathrm{E}$, and $\mathrm{K})$ is recommended to prevent possible deficiencies of fat-soluble vitamins, due to the interferences with the absorption of them.

Orlistat should be avoided in patients with chronic diarrhea $[4,20,21]$. Moreover, it can reduce the absorption of amiodarone [22], and ciclosporin [23] and can increase warfarin's action $[20,24]$. Systemic adverse effects are minimal because of the lack of systemic absorption.
3.1.2. Metformin. Metformin is an effective oral hypoglycemic agent used in the treatment of adults with type 2 diabetes and other conditions with insulin resistance [2527]. Its hypoglycemic effect is largely caused by inhibition of hepatic gluconeogenesis, increased insulin-mediated glucose disposal, and inhibition of fatty acid oxidation. Reduction of intestinal glucose absorption has been hypothesized as another possible mechanism of action, although data have been inconsistent [28]. The exact mechanism of intracellular action of metformin remains uncertain. Metformin is poorly metabolized, and $90 \%$ of the absorbed drug is eliminated as unchanged in urine. Plasma protein binding is insignificant, so the drug is dialyzable.

Metformin therapy for insulin resistance and obesity is safe and well tolerated and has a beneficial effect on weight, BMI, waist circumference, abdominal fat, fasting insulin, and fasting glucose although 6 months of therapy may not be sufficient to have an effect on visceral adipose tissue loss and insulin sensitivity [29]. Metformin is currently being used in more than 90 countries worldwide.

According to recent studies, the major effect of metformin may be a powerful inhibition of appetite under the light of the well-known role of weight excess on hypertension, type 2 diabetes, and dyslipidemia [30]. Because the major component of metabolic syndrome is weight excess, by contrasting it, this drug can also be able to prevent most of its consequences on health.

The potential clinical application of metformin in the pediatric population was first described in the 1970s in a small published study demonstrating the beneficial effect on weight and insulin concentrations in 8-14-year-old obese children [31]. Subsequent pediatric randomized, controlled trial studies have shown improvement in BMI, fasting serum glucose, insulin, and lipid profile in patients on metformin therapy for exogenous obesity associated with insulin resistance [9-11]. Participants received metformin for 6 months at a daily dose of $1 \mathrm{~g}$ ( $0.5 \mathrm{~g}$ twice daily) [11] or $2 \mathrm{~g}(1 \mathrm{~g}$ twice daily) [9]. There were no withdrawals due to adverse 
TABLE 3: Summary of studies about orlistat, metformin, and sibutramine in children and adolescents.

\begin{tabular}{|c|c|c|c|c|c|c|}
\hline $\begin{array}{l}\text { Authors and } \\
\text { year }\end{array}$ & Drug & $\begin{array}{l}\text { Population } \\
\text { treated }\end{array}$ & $\begin{array}{c}\text { Age } \\
\text { (years) }\end{array}$ & Duration & $\begin{array}{l}\text { Effects on BMI or other } \\
\text { metabolic effects }\end{array}$ & Adverse events \\
\hline $\begin{array}{l}\text { Chanoine et } \\
\text { al. } 2005 \text { [8] }\end{array}$ & Orlistat & $\begin{array}{l}357 \text { obese } \\
\text { adolescent }\end{array}$ & $12-16$ & 1 year & BMI: -0.55 SD & $\begin{array}{l}\text { Mild to moderate } \\
\text { gastrointestinal tract } \\
\text { adverse events } \\
(9 \%-50 \%)\end{array}$ \\
\hline $\begin{array}{l}\text { Srinivasan et } \\
\text { al. } 2006 \text { [9] }\end{array}$ & Metformin & 28 & $9-18$ & 6 months & $\begin{array}{l}\text { BMI: }-1.26 \mathrm{Kg} / \mathrm{m}^{2} \\
(P=.002) \text {; waist } \\
\text { circumference: }-2.8 \mathrm{~cm} \\
(P=.003) \text {; fasting insulin: } \\
-2.2 \mathrm{mU} / \text { liter }(P=.011)\end{array}$ & Nausea \\
\hline $\begin{array}{l}\text { Kay et al. } \\
2001[10]\end{array}$ & Metformin & 24 & $15.6 \pm 0.4$ & 8 weeks & $\begin{array}{l}\text { Body fat: }-6.0 \pm 0.62 \text {; } \\
\text { fat-free mass was similar in } \\
\text { metformin group and } \\
\text { placebo. Enhances insulin } \\
\text { sensitivity, significant } \\
\text { reduction in plasma leptin, } \\
\text { cholesterol, triglycerides, } \\
\text { and free fatty acid. }\end{array}$ & $\begin{array}{l}\text { Nausea, dizziness, and } \\
\text { stools }\end{array}$ \\
\hline $\begin{array}{l}\text { Freemark and } \\
\text { Bursey } 2001 \\
{[11]}\end{array}$ & Metformin & 29 & $12-19$ & 6 months & $\begin{array}{l}\text { BMI: decline of } 0.12 \text { SD and } \\
\text { a } 5.5 \% \text { reduction in serum } \\
\text { leptin in girls. Metformin } \\
\text { caused a progressive decline } \\
\text { in fasting blood glucose } \\
\text { and a reduction in fasting } \\
\text { insulin levels. }\end{array}$ & $\begin{array}{l}\text { Transient abdominal } \\
\text { discomfort or diarrhea }\end{array}$ \\
\hline $\begin{array}{l}\text { Jones et al. } \\
2002[12]\end{array}$ & Metformin & 82 & $10-16$ & 16 weeks & $\begin{array}{l}\text { Improved glycemic control, } \\
\text { the adjusted mean change } \\
\text { from baseline in fasting } \\
\text { plasma glucose was } \\
-2.4 \mathrm{mmol} / \mathrm{L} \text {. Mean } \mathrm{HbA}_{\mathrm{lc}} \\
\text { values was significantly } \\
\text { lower. }\end{array}$ & $\begin{array}{l}\text { Gastrointestinal side } \\
\text { effects (diarrhea) }\end{array}$ \\
\hline $\begin{array}{l}\text { Berkowitz et } \\
\text { al. } 2003[13]\end{array}$ & Sibutramine & 82 & $13-17$ & 6 months & BMI: $-8.5 \%$ & $\begin{array}{l}\text { Elevated blood pressure } \\
\text { and/or pulse rate, } \\
\text { ventricular premature } \\
\text { beats, cholelithiasis, } \\
\text { ecchymoses, and rash }\end{array}$ \\
\hline $\begin{array}{l}\text { Berkowitz et } \\
\text { al. } 2006[14]\end{array}$ & Sibutramine & 498 & $12-16$ & 12 months & $\begin{array}{l}\text { BMI: }-2.9 \mathrm{Kg} / \mathrm{m}^{2} \text {; body } \\
\text { weight: }-8.4 \mathrm{Kg}(P<.001 \\
\text { for both); greater } \\
\text { improvements in } \\
\text { triglyceride levels, } \\
\text { high-density lipoprotein } \\
\text { cholesterol levels, insulin } \\
\text { levels and sensitivity }\end{array}$ & Tachycardia \\
\hline $\begin{array}{l}\text { Garcia- } \\
\text { Morales et al. } \\
2006[15]\end{array}$ & Sibutramine & 46 & $14-18$ & 6 months & BMI: $-9.2 \%$ & $\begin{array}{l}\text { No significant difference } \\
\text { in blood pressure, } \\
\text { tachycardia, headache } \\
\text { with nausea, or weakness }\end{array}$ \\
\hline $\begin{array}{l}\text { Godoy-Matos } \\
\text { et al. } 2005 \\
{[16]}\end{array}$ & Sibutramine & 60 & $14-17$ & 6 months & $\begin{array}{l}\text { The mean BMI reduction } \\
\text { was greater in the } \\
\text { sibutramine group: } 3.6 \pm \\
2.5 \mathrm{Kg} / \mathrm{m}^{2}\end{array}$ & $\begin{array}{l}\text { No significant difference } \\
\text { in blood pressure or } \\
\text { heart rate }\end{array}$ \\
\hline
\end{tabular}


TABle 3: Continued.

\begin{tabular}{|c|c|c|c|c|c|c|}
\hline $\begin{array}{l}\text { Authors and } \\
\text { year }\end{array}$ & Drug & $\begin{array}{l}\text { Population } \\
\text { treated }\end{array}$ & $\begin{array}{c}\text { Age } \\
\text { (years) }\end{array}$ & Duration & $\begin{array}{l}\text { Effects on BMI or other } \\
\text { metabolic effects }\end{array}$ & Adverse events \\
\hline $\begin{array}{l}\text { Van Mil et al. } \\
2007[17]\end{array}$ & Sibutramine & 24 & $12-17$ & 12 weeks & $\begin{array}{l}\text { Effect on BMI-SDS not } \\
\text { significant }\end{array}$ & $\begin{array}{l}\text { Abdominal complaints, } \\
\text { insomnia, headache, loss } \\
\text { of interest, and loss of } \\
\text { appetite }\end{array}$ \\
\hline $\begin{array}{l}\text { Daniels et al. } \\
2007[18]\end{array}$ & Sibutramine & 498 & $12-16$ & 12 months & $\begin{array}{l}\text { BMI reduction was }>\text { or }= \\
5 \%\end{array}$ & $\begin{array}{l}\text { Small mean decreases in } \\
\text { blood pressure and pulse } \\
\text { rate were seen in both } \\
\text { sibutramine and placebo }\end{array}$ \\
\hline
\end{tabular}

events in either of the study; however, medication dose was lowered due to nausea in three participants (Freemark (2001) $n=1$; Srinivasan (2006) $n=2$ ). In both studies, there was no adverse effect on serum lactate, measures of liver, or renal function. Freemark et al. reported that there were no episodes of vomiting or lactic acidosis. Srinivasan et al., demonstrated that there was no biochemical evidence of metformin toxicity. In one study, three metformin-treated patients and one placebo patient complained of transient abdominal discomfort or diarrhea that resolved within the first one to two weeks of therapy, and another participant may have had an exacerbation of migraine [11].

Metformin treatment has been approved in children older than 10 years. The beneficial role of this drug in young patients with type 2 diabetes has been demonstrated in a randomized, controlled trial [12].

\subsection{Drugs Affecting Central Mechanisms}

3.2.1. Serotonin and Noradrenaline Reuptake Inhibitors (SNRIs). Anorectic medications targeting the 5-HT system are typically derived from beta-phenethylamine and mediate their effects by influencing noradrenergic, dopaminergic, and serotonergic neurotransmission [4].

Sibutramine. Sibutramine was originally developed as an antidepressant, and it is a centrally acting monoamine reuptake inhibitor that mainly acts to increase satiety [32]. Its most important mechanism of action is to block norepinephrine and 5-HT re-uptake, but it also stimulates thermogenesis that plays a minor role in weight reduction [33]. Sibutramine undergoes extensive first-pass metabolism, mainly by hepatic cytochrome p450 3A4 enzymes, toactivate primary and secondary amine metabolites that are more potent than the parent compound. The drug and its active metabolites are mainly excreted through the kidney [20].

Sibutramine was approved for adults in the US in 1997 and in the European Union in 1999. Consumer advocacy group Public Citizen campaigned to have sibutramine withdrawn from the market in the US, and two deaths in Italy led to an international investigation in 2002 and temporary removal from the market. In the US, sibutramine may be used in adolescents older than 16 years [34].

The addition of sibutramine to a behavior therapy program resulted in statistically significant improvements in BMI [13-17]. Berkowitz et al. reported that 7-12 months of sibutramine treatment decreased BMI by $2.4 \%$, respect to placebo [13]. In an RCT including 498 adolescents the same authors also showed a reduction of BMI and body weight, and an improvement of metabolic profile in the sibutraminetreated group [14].

Godoy-Matos et al. studied 60 Brazilian adolescents and documented that approximately $25 \%$ of adolescents assigned to the sibutramine group reduced their initial weight by at least $15 \%$ in comparison to $0 \%$ in the placebo group $(P<$ .001) [16].

A common landmark is that the efficacy of sibutramine is greatly enhanced when used with intensive lifestyle modification and behavior therapy [13-17].

The most common adverse effects found in adolescents taking sibutramine was tachycardia, even if generally it was not a reason to withdraw from treatment [13-16]. Other common side effects include insomnia, elevation of blood pressure, headache, dizziness, dry mouth, and constipation. Long-term data on the effect of sibutramine on major obesity-related morbidity are lacking. However, the ongoing Sibutramine Cardiovascular Outcomes trial (SCOUT) is assessing the efficacy of sibutramine in reducing myocardial infarction, stroke, and cardiovascular mortality in 9000 obese and overweight patients [35]. It is important to notice that sibutramine effects on heart rate and blood pressure in obese adolescents are generally neutralized by the effective reduction in BMI that seems to be even better than that observed in adults [18].

Phentermine. Phentermines' use is only approved for shortterm treatment of obesity in adults of up to 3 months duration due to the lack of long-term studies [36].

It has been demonstrated that, in subjects treated with phentermine, the weight loss was greater (from 2 to $10 \mathrm{~kg}$ ) than in those receiving placebo. Patients treated with phentermine at the dosage from $15 \mathrm{mg} / \mathrm{d}$ to $30 \mathrm{mg} / \mathrm{d}$ lost an average of $3.6 \mathrm{~kg}$ ( $95 \% \mathrm{CI}, 0.6$ to $6 \mathrm{~kg})$ of additional weight compared with placebo (the duration of treatment with phentermine varied from 2 to 24 weeks). The authors concluded that treatment with phentermine, in addition to lifestyle interventions, resulted in a statistically significant but modest increase in weight loss. In 1961-1963 Lorber carried out a trial including 84 children aged from 3 to 13 years to evaluate the effects of this new drug compared to placebo. Only 68 subjects completed the entire course of 12 weeks, divided into three period, of 4 weeks, during which three 
different types of treatment were prescribed (amphetamine resinate, phentermine, and diet with placebo). Authors concluded that phentermine was somewhat more efficient than both diet or the lower dose of amphetamine resinate, with very few side effects; however, the effectiveness tended to wear off after several months of treatment [37].

Side effects, since phentermine is a sympathomimetic amine, can be expected and include insomnia, dry mouth, constipation, restlessness, euphoria, nervousness, increased pulse rate, and blood pressure. The use of noradrenergic agents is thus not indicated in patients with cardiovascular disease, hypertension, and history of drug abuse or in those taking monoamine oxidase inhibitors [21].

3.2.2. Selective Inhibitors of Serotonin Reuptake. Fluoxetine and sertraline are selective inhibitors of 5-HT reuptake despite different chemical structures. Fluoxetine is a phenylpropanolamin oxy-3-fluorphenyl derivate, and sertraline is a naftilaminic one. They inhibit 5 -HT re-uptake at the presynaptic terminal, and their main indication use is in the treatment of depression and bulimia. They are not formally indicated to treat obesity [38], but fluoxetine was used in adult patients to control hyperphagia, and consequently obesity correlated with syndromic condition, such as PraderWilli syndrome [39].

These agents were found to reduce feeding in experimental animals. In humans, protocol studies, performed to approve these medications as antidepressants, demonstrated weight loss in treated subjects. The key problem in managing these agents is weight regain. Generally, after the first 6 months of treatment, body weight is gradually recovered, although medication is maintained. Fluoxetine therapy for obesity management has also been associated with GIT symptom, sleep disorders, reduced libido, sweating, amnesia, and thirst [40]. Until now no trials exist about their use to treat childhood obesity.

3.2.3. Octreotide. Octreotide is a synthetic, eight-aminoacid analogue of the natural hormone somatostatin. Like somatostatin, octreotide limits $\beta$-cell insulin secretion by inhibiting the G0 protein associated with the widening of the voltage-gated calcium channel [41]. It also inhibits secretion of gastric acid, pancreatic enzymes, and bile, prolongs intestinal transit time, and decreases gallbladder contractility. Somatostatin and octreotide inhibit the release of pituitary and gastro-entero-pancreatic hormones such as growth hormone $(\mathrm{GH})$, thyroid stimulating hormone (TSH), glucagon, cholecystokinin (CCK), vasoactive intestinal peptide (VIP), gastrin, and ghrelin [42-44].

Octreotide has been previously shown in both pilot [45] and placebo-controlled trials [46] to be effective in reducing insulin secretion, weight, and BMI in children with hypothalamic obesity. In a pilot study, including obese adults, suppression of insulin secretion was achieved after a 24-week treatment with octreotide long acting (40 mg), and it was associated with both body weight and fat mass loss [47].

The most common adverse events were diarrhea, headache, cholelithiasis, nausea, and abdominal pain [48].
The parenteral administration is one of the major problems in long-term treatment.

3.2.4. Caffeine/Ephedrine. Lipolysis in white and brown adipocytes is activated by sympathetic stimulation of $\beta$ adrenoreceptors. In rodents, the $\beta 3$-adrenoceptor plays the dominant role in these cells. This partly explains why $\beta 3$ adrenoceptor agonists are highly effective in causing weight loss and improving insulin sensitivity in animal models of obesity and type 2 diabetes. The role of the $\beta 3$-adrenoceptor in humans is more controversial. The $\beta 3$-adrenoceptor mRNA is expressed in human adipose tissue, but in lower amounts than in rodents. The receptor is more abundant in multilocular than in unilocular adipocytes. Its abundance is lower in adipocytes of obese subjects than lean ones, but therapy with ephedrine and caffeine increased its expression in obese population.

The ephedrine promotes noradrenaline release as well as causes some direct stimulation of adrenoreceptors, and in association with caffeine it enhances sympathetic activity. Indeed, in humans there is evidence that the thermogenic effect of ephedrine is in part mediated by $\beta 3$-adrenoceptors [49] and that the $\beta 3$-adrenoceptor-mediated component of this effect is enhanced by repeated administration of ephedrine or ephedrine plus caffeine $[50,51]$.

Clinical studies demonstrated that obese subjects' body composition, resting energy expenditure, and lipid metabolism are overall compatible with a more pronounced thermogenic and lipolytic effect by ephedrine plus caffeine plus energy restriction as compared to energy restriction alone [52]. Molnàr et al., in 2000, have published data about a pilot randomized double-blind placebo-controlled trial in 32 obese adolescents for 20 weeks, demonstrating that caffeine/ephedrine can be a safe and effective compound for the treatment of obesity in adolescents, with negligible adverse events [53].

3.3. New and Future Drugs. Recent advances in the understanding of energy balance control have resulted in the exploitation of a large number of new targets, some of which have yielded promising data in clinical trials for weight loss. A second major trend is derived from the hypothesis that improved weight loss efficacy over current therapy is more likely to emerge from treatments targeting multiple mechanisms of energy balance control. Many of these approaches also utilize advances in formulation technology to widen safety margins. Finally, the practicality of peptide therapies for obesity has become better validated in recent studies, and this may allow more rapid exploitation of novel targets, rather than awaiting the development of orally available small molecules [20]. Despite the limitations of current drugs and their declining use in some jurisdiction, anti-obesity drugs still accounted for sales of nearly a halfbillion US dollars in the seven largest global markets during 2000 [54, 55]. Since overall sales of anti-obesity drugs projected to at least triple by 2010 [56], development of effective drugs has become a research priority and an area of intense clinical interest. 
The new anti-obesity drugs under clinical development include agents affecting peripheral and central mechanisms. In the first group, we can include gastrointestinal lipase inhibitor (cetilistat), amylin and leptin analogs, thermogenic agents, that is, selective $\beta 3$ receptor agonists, agonist of the glucagon-like peptide 1 (GLP-1) (Exendin-4, Liraglutide). In the second group, we can consider agents that modulate the central activity of neuropeptides influencing food intake and including antiepilepsy drugs (topiramate, zonisamide), noradrenaline and dopamine reuptake inhibitors (bupropion, tesofensine) that were studied in monotherapy or in combination (bupropion-naltrexone and phenterminetopiramate); human ciliary neurotrophic factor (axokine), human GH fragment (AOD9604, AOD9401), melanocortin receptor selective agonists (MC4R), melanin-concentrating hormone antagonists, serotoninergic drugs including selective 5-HT2C receptor agonists (lorcaserin), components of neuropeptide Y (NPY) signaling pathway (CAMKK2).

We briefly cite these new drugs, although there are not yet studies in pediatric population, because these promising, more efficacious, and better-tolerated treatments for obesity may become available in the coming future also in pediatric population.

\subsubsection{Drugs Affecting Peripheral Mechanisms}

Cetilistat. Cetilistat (ATL-962) is a novel gastrointestinal lipase inhibitor. A phase II, multicentre, randomized, placebo-controlled, parallel group study demonstrated that treatment with cetilistat reduced mean body weight to similar extents at all doses, which were statistically significant compared with placebo. Adverse events were generally mild to moderate in intensity, occurred only on one occasion and mostly GIT in nature (such as flatus with discharge and oily spotting). Other lipase inhibitors are under investigation for obesity treatment [57].

Pramlintide. Pramlintide (Pro25, Pro28, Pro29-amylin), a soluble synthetic analogue of amylin, is approved in US as an adjunct to insulin for subcutaneous use in patients with type 1 or type 2 diabetes who are not able to achieve glucose control through optimal insulin therapy. Despite the wellknown association between insulin and weight gain, insulintreated type 1 or type 2 diabetic patients receiving adjunctive treatment with pramlintide demonstrated lower hemoglobin glycosylated levels as well as a significant and sustained reduction in body weight and BMI [4]. Pramlintide seems to mediate its anorectic effects (at least in part) through delayed GIT motility.

Recently, an association with metreleptin showed interesting results [58]. In fact, metreleptin, a leptin agonist, leads to weight loss that resulted significantly greater if associated with pramlintide. The greater reduction in body weight was significant as early as week 4 , and weight loss continued throughout the study, without evidence of a plateau.

The most common adverse effects with pramlintide/metreleptin were injection site events and nausea, which were mostly mild to moderate and decreased over time.
Beta3-Adrenoceptor Agonists. $\beta 3$-adrenoceptor is the predominant subtype of adrenoceptor expressed in adipose tissue. It mediates the major effects of adrenaline and noradrenaline in adipose tissues, such as lipolysis in white adipose tissue and thermogenesis in brown adipose tissue. $\beta 3$-adrenoceptor agonist CL.316243 increases fat oxidation and decreases carbohydrate oxidation in humans [59]. Many pharmaceutical companies have attempted to develop $\beta 3-$ adrenoceptor agonists for the treatment of human obesity, but there is no report on a compound that has progressed beyond phase II clinical trials [60]. Even though many companies have lost interest in the potential of $\beta 3$-adrenoceptor agonists for the treatment of obesity and diabetes, they can offer useful perspectives on pharmacology, physiology, and obesity drug discovery $[4,60]$.

Exendin-4, Liraglutide. The combination of anorectic and incretin effects of GLP-1 and analogues has attracted much attention as potential treatment for type 2 diabetes.

Exendin-4 (exenatide) is a natural agonist of the GLP-1 receptor isolated from the lizard Heloderma suspectum and has longer biological activity than GLP-1. It was recently approved for the treatment of type 2 diabetes. Twice daily subcutaneous administration of exenatide in patients with type 2 diabetes led to a dose-dependent weight loss of 1.8 $\pm 0.3 \mathrm{~kg}$ over 28 days, $2.8 \pm 0.5 \mathrm{~kg}$ over 30 weeks, and $4.7 \pm$ $0.3 \mathrm{~kg}$ over 2 years [61].

Liraglutide is a GLP-1 analogue with $97 \%$ primary amino acid homology to native GLP-1, recently approved in Europe and under evaluation by the FDA in the US. Like exenatide, liraglutide has been associated with dose-dependent weight loss in addition to metabolic and cardiovascular benefits: hemoglobin glycosylated decrease, improvements in triglyceride levels, a mean reduction in systolic and diastolic blood pressure [62].

Although actual interest in GLP-1 agonists has focused on their incretin effects for the development of therapeutics treatment of diabetes $[63,64]$, it seems likely that obesity indications will also be reached in the near future, although these might be limited to obese diabetic patient populations [4].

\subsection{Drugs Affecting Central Mechanisms}

3.4.1. Topiramate, Zonisamide, Bupropion, and Tesofensine. Two antiepileptic drugs (topiramate and zonisamide) and the antidepressant bupropion have been studied for their weight loss effects.

The mechanisms by which antiepileptic drugs produce weight loss are unclear, but they may be due to the antagonism of the glutamate kinase receptor by topiramate and to the serotonergic and dopaminergic activities of zonisamide [65]. Topiramate therapy was demonstrated to bring on a high frequency of adverse events due to the central and peripheral nervous system, such as paresthesias, somnolence, and difficulty with memory; for this reason, trials have been stopped in phase III while the manufacturers were going to develop an extended release formulation. Zonisamide's 
adverse events occurring in the treatment group were fatigue and a small but significant increase in serum creatinine [65].

In an 8-week-study of weight loss in overweight and obese women, bupropion, currently marketed for treatment of depression and as a smoking cessation aid, produced a $6.2 \%$ loss of body weight compared with $1.6 \%$ weight loss in the placebo group $[65,66]$. Clinicians must be aware of the $0.4 \%$ risk of seizure when the drug dose is $400 \mathrm{mg} /$ day. The mechanism through which the drug leads to weight loss may be the inhibition of nor-epinephrine and dopamine uptake [65]. The pooled random-effects estimate of weight loss in bupropion-treated patients compared with placebo recipients was $2.77 \mathrm{~kg}$ (95\% CI, 1.1 to $4.5 \mathrm{~kg}$ ) [66], and the same authors indicate that the total weight loss in the bupropion-treated patients was $4.44 \mathrm{~kg}$. In the adverse events analysis, there was an increase in dry mouth (pooled odds ratio:3.26 ; relative risk: 2.99 ) and no significant increases in diarrhea and constipation. In addition to dry mouth, insomnia is a commonly reported side effect in these studies [66].

Tesofensine is a new drug producing weight loss in obese individuals. It inhibits the presynaptic re-uptake of the neurotransmitters noradrenaline, dopamine, and serotonin. In phase II clinical trials with tesofensine in obese individuals, dose-related reductions in body weight, body fat, and waist circumference, as well as improvements in other obesity-related endocrine factors, were observed, while it was associated with minor adverse events, such as elevations in heart rate and blood pressure at the highest dose tested [67].

There are no recent data available on the use of these drugs in pediatric populations.

3.4.2. Bupropion-Naltrexone (Contrave). Contrave is an oral, sustained release combination of the dopamine and norepinephrine re-uptake antagonist bupropion and the opioid antagonist naltrexone. The mechanism of action of the compound involves complementary stimulation of central melanocortin pathways, resulting in increased energy expenditure and reduced appetite. Preliminary data of phase III clinical trials in adults demonstrated placebo-subtracted weight loss of 3 to $7 \%$ and improvements in obesity-related comorbidities and cardiovascular risk factors $[68,69]$.

3.4.3. Phentermine-Topiramate. We have cited before the specific characteristic of phentermine and topiramate, but phentermine $\mathrm{HCI} /$ topiramate controlled-release (PHEN/ TPM CR) is a combination agent containing immediaterelease phentermine and controlled-release topiramate. Clinical trials involving thousands of patients demonstrate PHEN/TPM CR to be effective in improving the weight and also the adiposopathy-associated metabolic diseases [70].

\subsubsection{Endocannabinoid Receptor Blockers (Rimonabant,} Taranabant). Endocannabinoid (ECB) receptor blockers, such as rimonabant, were initially intended as an antiobesity and smoking cessation dual-purpose drug; however, the latter development program has been discontinued [20,
71]. ECB produces a dose-dependent reduction in food intake in various rodent models, and these effects seem to be both centrally and peripherally mediated [72]. Potential peripheral mechanisms include enhanced thermogenesis increasing oxygen consumption in skeletal muscle [73], reducing hepatic [74] and adipocyte lipogenesis [75], augmenting adiponectin concentrations [76], promoting vagusmediated cholecystokinin-induced satiety $[77,78]$, inhibiting preadipocyte proliferation, and increasing adipocyte maturation without lipid accumulation [79].

Rimonabant in the United Kingdom was indicated for patients whose BMI exceeds $30 \mathrm{~kg} / \mathrm{m}^{2}$ or who had associated factors such as type 2 diabetes and/or dyslipidemia, while in other countries obesity alone was not an indication for its use and abnormal blood lipid levels are also required for the prescription [80]. Recently European Medicines Agency decided the withdrawal of rimonabant from the European market because of its important side effects.

Taranabant is a novel cannabinoid CB1 receptor inverse agonist that is in clinical development for the treatment of obesity. Mechanism-of-action studies suggest that engagement of the CB1 receptor by taranabant leads to weight loss by reducing food intake and increasing energy expenditure and fat oxidation [81]. Recent studies have demonstrated a weight loss after a 12-week therapy in obese adults, inducing statistically significant weight loss compared to placebo in obese subjects over the entire range of evaluated doses $(0.5,2$, 4 , and $6 \mathrm{mg}$ once per day) $(P<.001)$. Taranabant treatment was associated with dose-related increased incidence of clinical adverse events, including mild to moderate GIT and psychiatric effects.

3.4.5. Ciliary Neurotrophic Factor. Ciliary neurotrophic factor (CNTF) was originally characterized as a trophic factor supporting the survival of embryonic chick ciliary ganglion neurons in vitro $[82,83]$. Initially, CNTF was described as being predominantly distributed within neural tissues [84] but it was also reported in skeletal muscle, adrenal gland, sciatic nerve, skin, kidney, and testes [85]. Although CNTF was firstly identified as a trophic factor in the ciliary ganglion, it was later found to act on other motor neuron populations [86]. Hence, it was evaluated as a therapeutic tool in patients suffering from motor neuron diseases [87]. Interestingly, during these trials, CNTF administration resulted in unexpected weight loss. CNTF can also cross the blood-brain barrier in a manner similar to leptin [88]. CNTF and its synthetic analogue, axokine, have also been found to suppress NPY gene expression [89]. It is believed to occur by resetting the hypothalamic weight set point, such that cessation of CNTF treatment does not result in overeating and rebound weight gain [90]. The results of recent studies have suggested that CNTF and axokine may play a role in the regulation of adipocyte metabolism and, perhaps, the control of adipose tissue mass, supporting the hypothesis that weight loss due to CNTF is not solely mediated by the CNS [91].

CNTF or axokine [92] failed first phase III trial because two-thirds of the patients developed antibodies against this factor. Thus, further studies have to be made to understand the effectiveness of the drug and its possible side effects. 
3.4.6. Analogue (AOD9604-AOD9401) of Human Growth Hormone. It has generally been recognized that human GH (hGH) exerts a profound effect on body composition and systemic hGH administration reduces body fat mass as well as fat distribution. The use of hGH for the treatment of human obesity has not been advocated due to serious side effects, including glucose intolerance, insulin resistance, sodium retention, hypertension, edema, and carpal tunnel syndrome [93].

The aminoterminus of the hGH molecule is the functional domain for the insulin-like action of the hormone. Some studies have identified the specific metabolic domain responsible for the lipolytic/antilipogenic activity of the hGH molecule, referred as AOD9604 and studied for its metabolic actions in obese rats. Daily treatment with an oral dose of AOD9604 $(500 \mu \mathrm{g} / \mathrm{kg})$ for 19 days reduced over $50 \%$ of body weight gain of the animals in comparison with the control. The adipose tissues of the AOD9604treated animals were found to present an increase in lipolytic activity. In contrast to chronic treatment with intact hGH, the chronic treatment with AOD9604 showed no adverse effect on insulin sensitivity, as demonstrated with euglycemic clamp techniques [94]. Unfortunately, AOD9604 recently failed phase IIb trials for obesity.

Another lipolytic domain (referred as AOD9401) of $\mathrm{hGH}$, has been synthesized using solid-phase peptide synthesis techniques. This analogue of the hGH lipolytic domain may have the potential to be developed into an orally usable and safe therapeutic agent for obesity. Up to now, no human studies have been yet performed [94].

3.4.7. Melanocortin Receptor Selective (MC4R) Agonists. Much effort is currently underway to develop melanocortin receptor selective compounds directed for clinical use, with a focus on the development of MC4R selective agonists to treat obesity. There is, on the other hand, the possibility of treating anorectic and cachectic conditions with MC4R antagonists [95].

The most reported side effects of this drug appear to be mild and include flushing, somnolence, nausea, vomiting, headache, and taste disturbances $[54,96]$. The only available clinical trial data on the effect of an MC4R agonist was conducted with adrenocorticotropic hormone (an agonist of MC4R) to assess its potential to cause weight reduction in humans. Therefore, clinical trials with proper drug candidates are needed.

3.4.8. Melanin-Concentrating Hormone (MCH) Antagonists. MCHR1 antagonists (recently patented) [97, 98] are one class of agents that shows particularly good promise for treating obesity that has now been well validated in animal models but remains to be validated in human clinical trials. MCHR1 antagonists reduce food intake, particularly highly palatable food, and subsequently decreases body weight, primarily due to decreased fat mass. Depending upon the animal model and paradigm utilized in the studies, MCHR1 antagonists also were shown to increase energy expenditure resulting in weight loss. Together, these data suggest that
MCHR1 antagonists may be a key component in a program of diet, exercise, and therapeutic intervention in reducing the energy "gap" to allow people better regulation of their weight. A number of significant safety, selectivity, and metabolic stability hurdles were presented that continue to be challenges for pharmaceutical companies in their effort/research to be the first to deliver a new therapeutic agent targeting this receptor. Since, to date, only three companies have initiated clinical trials, and only one has reported conclusion of a first-in-human trial there is still a long road and many years ahead before a compound targeting MCHR1 receptors could ultimately be marketed for the treatment of obesity [98].

3.4.9. Serotonergic Drugs. M-chlorophenylpiperazine (mCPP) is a 5-HT2C receptor agonist studied in insulin resistant mouse models showing beneficial effects on glucose homeostasis and weight gain [40]. Diet-induced obese mice and leptin-deficient (ob/ob) mice treated for 2 weeks exhibited a dramatic 50\% reduction in plasma insulin levels in both models. This was without effects on blood glucose, food intake, activity, or body mass at the doses used in this study. Pharmacological blockage of 5-HT2C receptors abolished effects on glucose tolerance, verifying that these effects were directly mediated by 5 -HT2C receptors [97]. $\mathrm{mCPP}$ has been shown to modify appetite in both lean and obese humans.

A new generation of 5-HT2C receptor agonist is developing [97]. Recent studies show APD-356 (lorcaserin) to be a potent, selective, and efficacious agonist of the 5-HTC2 receptor, with potential for the treatment of obesity [99].

3.4.10. $\mathrm{Ca}^{2+} /$ Calmodulin-Dependent Protein Kinase Kinase 2 (CaMKK2). Recently, the adenosine monophosphatedependent protein kinase (AMPK) was identified as one component of NPY signaling pathway. Acute intracerebroventricular (icv) administration of a CaMKK2 null mice resulted in decreased food intake that was correlated with decreased hypothalamic NPY and AgRP mRNAs. The absence of CaMKK2 was also demonstrated to protect mice from diet-induced weight gain, hyperglycemia, and insulin resistance. Furthermore, icv infusion of the selective CaMKK2 inhibitor STO-609 in adult WT mice resulted in the acute suppression of NPY expression and food intake. The resistance of CaMKK2 null mice to suppression of food intake by STO-609 infusion provides compelling evidence that CaMKK2 is the direct target of the drug and that the specific inhibition of CaMKK2 in NPY neurons is likely responsible for the reduced level of NPY and AgRP mRNAs and feeding behavior [100].

Thus, the behavior of CaMKK2 null mice on the high-fat diet underscores the value of targeting CaMKK2 as a possible therapeutic locus in the treatment of obesity and diabetes [100].

\section{Conclusions}

Childhood obesity is not only a cosmetic problem. Many adverse health effects associated with adult obesity are 
already being seen in obese adolescents in which a significant increase in the cardiovascular risk has been observed, probably due to obesity-metabolic disarrangement (most incidence of hypertension, type 2 diabetes, and dyslipidemia), but also other co-morbidities such as nonalcoholic fatty liver disease, idiopathic intracranial hypertension, sleep apnea, and orthopedic abnormalities. In summary, there is insufficient evidence to conclude that any one-treatment approaches is superior in the management of adolescent obesity. However, the use of psychological interventions such us behavioral therapy and cognitive behavioral therapy, combined with strategies to improve diet and physical activity, shows promise.

The neurobiology of obesity is extremely complex with many overlapping and redundant pathways. This complexity decreases the probability that targeting any single pathway will result in dramatic weight loss and suggests that multiple drugs with different mechanisms will be needed to determine significant and persistent weight loss [20]. Although newer drugs are years away from clinical use, the hope for research investments made to date is translation into safe and effective anti-obesity drugs in the future. The search for novel drug treatments for obesity in childhood and adolescents is, therefore, both legitimate and necessary.

However, in our efforts to fill the therapeutic void that characterizes contemporary obesity management, the benefits of obesity pharmacotherapy must outweigh the risks and costs.

\section{References}

[1] T. Lobstein, L. Baur, and R. Uauy, "Obesity in children and young people: a crisis in public health," Obesity Reviews, vol. 5, no. 1, pp. 4-104, 2004.

[2] Y. Wang and T. Lobstein, "Worldwide trends in childhood overweight and obesity," International Journal of Pediatric Obesity, vol. 1, no. 1, pp. 11-25, 2006.

[3] V. Shrewsbury and J. Wardle, "Socioeconomic status and adiposity in childhood: a systematic review of cross-sectional studies 1990-2005," Obesity, vol. 16, no. 2, pp. 275-284, 2008.

[4] D. Cooke and S. Bloom, "The obesity pipeline: current strategies in the development of anti-obesity drugs," Nature Reviews Drug Discovery, vol. 5, no. 11, pp. 919-931, 2006.

[5] S. Arora and Anubhuti, "Role of neuropeptides in appetite regulation and obesity-a review," Neuropeptides, vol. 40, no. 6, pp. 375-401, 2006.

[6] J. P. H. Wilding, "Neuropeptides and appetite control," Diabetic Medicine, vol. 19, no. 8, pp. 619-627, 2002.

[7] G. P. August, S. Caprio, I. Fennoy et al., "Prevention and treatment of pediatric obesity: an endocrine society clinical practice guideline based on expert opinion," Journal of Clinical Endocrinology and Metabolism, vol. 93, no. 12, pp. 4576-4599, 2008.

[8] J.-P. Chanoine, S. Hampl, C. Jensen, M. Boldrin, and J. Hauptman, "Effect of orlistat on weight and body composition in obese adolescents: a randomized controlled trial," Journal of the American Medical Association, vol. 293, no. 23, pp. 2873-2883, 2005.

[9] S. Srinivasan, G. R. Ambler, L. A. Baur et al., "Randomized, controlled trial of metformin for obesity and insulin resistance in children and adolescents: improvement in body composition and fasting insulin," Journal of Clinical Endocrinology and Metabolism, vol. 91, no. 6, pp. 2074-2080, 2006.

[10] J. P. Kay, R. Alemzadeh, G. Langley, L. D’Angelo, P. Smith, and S. Holshouser, "Beneficial effects of metformin in normoglycemic morbidly obese adolescents," Metabolism, vol. 50, no. 12, pp. 1457-1461, 2001.

[11] M. Freemark and D. Bursey, "The effects of metformin on body mass index and glucose tolerance in obese adolescents with fasting hyperinsulinemia and a family history of type 2 diabetes," Pediatrics, vol. 107, no. 4, p. E55, 2001.

[12] K. L. Jones, S. Arslanian, V. A. Peterokova, J.-S. Park, and M. J. Tomlinson, "Effect of metformin in pediatric patients with type 2 diabetes: a randomized controlled trial," Diabetes Care, vol. 25, no. 1, pp. 89-94, 2002.

[13] R. I. Berkowitz, T. A. Wadden, A. M. Tershakovec, and J. L. Cronquist, "Behavior therapy and sibutramine for the treatment of adolescent obesity: a randomized controlled trial," Journal of the American Medical Association, vol. 289, no. 14, pp. 1805-1812, 2003.

[14] R. I. Berkowitz, K. Fujioka, S. R. Daniels et al., "Effects of sibutramine treatment in obese adolescents: a randomized trial," Annals of Internal Medicine, vol. 145, no. 2, pp. 81-90, 2006.

[15] L. M. García-Morales, A. Berber, C. C. Macias-Lara, C. Lucio-Ortiz, B. E. Del-Rio-Navarro, and L. M. DorantesAlvárez, "Use of sibutramine in obese mexican adolescents: a 6-month, randomized, double-blind, placebo-controlled, parallel-group trial," Clinical Therapeutics, vol. 28, no. 5, pp. 770-782, 2006.

[16] A. Godoy-Matos, L. Carraro, A. Vieira et al., "Treatment of obese adolescents with sibutramine: a randomized, doubleblind, controlled study," Journal of Clinical Endocrinology and Metabolism, vol. 90, no. 3, pp. 1460-1465, 2005.

[17] E. G. A. H. Van Mil, K. R. Westerterp, A. D. M. Kester, H. A. Delemarre-van De Waal, W. J. M. Gerver, and W. H. M. Saris, "The effect of sibutramine on energy expenditure and body composition in obese adolescents," Journal of Clinical Endocrinology and Metabolism, vol. 92, no. 4, pp. 1409-1414, 2007.

[18] S. R. Daniels, B. Long, S. Crow et al., "Cardiovascular effects of sibutramine in the treatment of obese adolescents: results of a randomized, double-blind, placebo-controlled study," Pediatrics, vol. 120, no. 1, pp. e147-e157, 2007.

[19] J. B. Hauptman, F. S. Jeunet, and D. Hartmann, "Initial studies in humans with the novel gastrointestinal lipase inhibitor Ro 18-0647 (tetrahydrolipstatin)," American Journal of Clinical Nutrition, vol. 55, no. 1, pp. 309S-313S, 1992.

[20] R. S. Padwal and S. R. Majumdar, "Drug treatments for obesity: orlistat, sibutramine, and rimonabant," The Lancet, vol. 369, no. 9555, pp. 71-77, 2007.

[21] Z. Li, M. Maglione, W. Tu et al., "Meta-analysis: pharmacologic treatment of obesity," Annals of Internal Medicine, vol. 142, no. 7, pp. 532-546, 2005.

[22] J. Zhi, R. Moore, L. Kanitra, and T. E. Mulligan, "Effects of orlistat, a lipase inhibitor, on the pharmacokinetics of three highly lipophilic drugs (amiodarone, fluoxetine, and simvastatin) in healthy volunteers," Journal of Clinical Pharmacology, vol. 43, no. 4, pp. 428-435, 2003.

[23] J. Zhi, R. Moore, L. Kanitra, and T. E. Mulligan, "Pharmacokinetic evaluation of the possible interaction between selected concomitant medications and orlistat at steady state in healthy subjects," Journal of Clinical Pharmacology, vol. 42, no. 9, pp. 1011-1019, 2002. 
[24] R. S. MacWalter, H. W. Fraser, K. M. Armstrong, G. RiveraMiranda, and P. Dion, "Orlistat enhances warfarin effect," Annals of Pharmacotherapy, vol. 37, no. 4, pp. 510-512, 2003.

[25] A. Saenz, I. Fernandez-Esteban, A. Mataix, M. Ausejo, M. Roque, and D. Moher, "Metformin monotherapy for type 2 diabetes mellitus," Cochrane Database of Systematic Reviews, no. 3, Article ID CD002966, 2005.

[26] R. A. Jackson, M. I. Hawa, J. B. Jaspan et al., "Mechanism of metformin action in non-insulin-dependent diabetes," Diabetes, vol. 36, no. 5, pp. 632-640, 1987.

[27] S. Srinivasan, G. R. Ambler, L. A. Baur et al., "Randomized, controlled trial of metformin for obesity and insulin resistance in children and adolescents: improvement in body composition and fasting insulin," Journal of Clinical Endocrinology and Metabolism, vol. 91, no. 6, pp. 2074-2080, 2006.

[28] M. Stumvoll, N. Nurjhan, G. Perriello, G. Dailey, and J. E. Gerich, "Metabolic effects of metformin in non-insulindependent diabetes mellitus," The New England Journal of Medicine, vol. 333, no. 9, pp. 550-554, 1995.

[29] K. Cusi, A. Consoli, and R. A. Defronzo, "Metabolic effects of metformin on glucose and lactate metabolism in noninsulindependent diabetes mellitus," Journal of Clinical Endocrinology and Metabolism, vol. 81, no. 11, pp. 4059-4067, 1996.

[30] W. C. Knowler, E. Barrett-Connor, S. E. Fowler et al., "Reduction in the incidence of type 2 diabetes with lifestyle intervention or metformin," The New England Journal of Medicine, vol. 346, no. 6, pp. 393-403, 2002.

[31] A. Lutjens and J. L. J. Smit, "Effect of biguanide treatment in obese children," Helvetica Paediatrica Acta, vol. 31, no. 6, pp. 473-480, 1976.

[32] W. McNeely and K. L. Goa, "Sibutramine. A review of its contribution to the management of obesity," Drugs, vol. 56, no. 6, pp. 1093-1124, 1998.

[33] M. E. Lean, "How does sibutramine work?" International Journal of Obesity, vol. 25, 4, pp. S8-S11, 2001.

[34] S. E. Barlow, "Expert committee recommendations regarding the prevention, assessment, and treatment of child and adolescent overweight and obesity: summary report," Pediatrics, vol. 120, pp. S164-192, 2007.

[35] W. F. Coutinho, "The obese older female patient: CV risk and the SCOUT study," International Journal of Obesity, vol. 31, no. 2, pp. S26-S30, 2007.

[36] J. Korner and L. J. Aronne, "Pharmacological approaches to weight reduction: therapeutic targets," Journal of Clinical Endocrinology and Metabolism, vol. 89, no. 6, pp. 2616-2621, 2004.

[37] J. Lorber, "Obesity in childhood. A controlled trial of anorectic drugs," Archives of Disease in Childhood, vol. 41, no. 217, pp. 309-312, 1966.

[38] M. C. Mancini and A. Halpern, "Pharmacological treatment of obesity," Arquivos Brasileiros de Endocrinologia e Metabologia, vol. 50, no. 2, pp. 377-389, 2006.

[39] J. K. Warnock, A. H. Clayton, H. A. Shaw, and T. O'Donnell, "Onset of menses in two adult patients with Prader-Willi syndrome treated with fluoxetine," Psychopharmacology Bulletin, vol. 31, no. 2, pp. 239-242, 1995.

[40] J. C. G. Halford, J. A. Harrold, E. J. Boyland, C. L. Lawton, and J. E. Blundell, "Serotonergic drugs: effects on appetite expression and use for the treatment of obesity," Drugs, vol. 67 , no. 1 , pp. 27-55, 2007.

[41] S. W. J. Lamberts, A.-J. van der Lely, W. W. de Herder, and L. J. Hofland, "Drug therapy: octreotide," The New England Journal of Medicine, vol. 334, no. 4, pp. 255-260, 1996.
[42] A. J. Krentz, P. J. Boyle, L. M. Macdonald, and D. S. Schade, "Octreotide: a long-acting inhibitor of endogenous hormone secretion for human metabolic investigations," Metabolism, vol. 43, no. 1, pp. 24-31, 1994.

[43] A. M. Haqq, D. D. Stadler, R. G. Rosenfeld et al., "Circulating ghrelin levels are suppressed by meals and octreotide therapy in children with Prader-Willi syndrome," Journal of Clinical Endocrinology and Metabolism, vol. 88, no. 8, pp. 3573-3576, 2003.

[44] H. J. Grill and G. P. Smith, "Cholecystokinin decreases sucrose intake in chronic decerebrate rats," American Journal of Physiology, vol. 254, no. 6, pp. 853-856, 1988.

[45] R. H. Lustig, F. Greenway, P. Velasquez-Mieyer et al., "A multicenter, randomized, double-blind, placebo-controlled, dose-finding trial of a long-acting formulation of octreotide in promoting weight loss in obese adults with insulin hypersecretion," International Journal of Obesity, vol. 30, no. 2, pp. 331-341, 2006.

[46] R. H. Lustig, P. S. Hinds, K. Ringwald-Smith et al., "Octreotide therapy of pediatric hypothalamic obesity: a double-blind, placebo-controlled trial," Journal of Clinical Endocrinology and Metabolism, vol. 88, no. 6, pp. 2586-2592, 2003.

[47] P. A. Velasquez-Mieyer, P. A. Cowan, K. L. Arheart et al., "Suppression of insulin secretion is associated with weight loss and altered macronutrient intake and preference in a subset of obese adults," International Journal of Obesity, vol. 27, no. 2, pp. 219-226, 2003.

[48] S. Ezzat, P. J. Snyder, W. F. Young et al., "Octreotide treatment of acromegaly: a randomized, multicenter study," Annals of Internal Medicine, vol. 117, no. 9, pp. 711-718, 1992.

[49] Y.-L. Liu, S. Toubro, A. Astrup, and M. J. Stock, "Contribution of $\beta 3$-adrenoceptor activation to ephedrine induced thermogenesis in humans," International Journal of Obesity, vol. 19, no. 9, pp. 678-685, 1995.

[50] A. Astrup, C. Lundsgaard, J. Madsen, and N. J. Christensen, "Enhanced thermogenic responsiveness during chronic ephedrine treatment in man," American Journal of Clinical Nutrition, vol. 42, no. 1, pp. 83-94, 1985.

[51] F. Greenway, L. de Jonge, E. Tucker, J. Rood, and S. Smith, "Caffeine and ephedrine become more beta- 3 selective with time," Obesity Research, vol. 8, supplement 1, pp. 70-82, 2000.

[52] R. De Matteis, J. R. S. Arch, M. L. Petroni, D. Ferrari, S. Cinti, and M. J. Stock, "Immunohistochemical identification of the $\beta 3$-adrenoceptor in intact human adipocytes and ventricular myocardium: effect of obesity and treatment with ephedrine and caffeine," International Journal of Obesity, vol. 26, no. 11, pp. 1442-1450, 2002.

[53] D. Molnár, K. Török, E. Erhardt, and S. Jeges, "Safety and efficacy of treatment with an ephedrine/caffeine mixture. The first double-blind placebo-controlled pilot study in adolescents," International Journal of Obesity, vol. 24, no. 12, pp. 1573-1578, 2000.

[54] M. Hallschmid, R. Smolnik, G. McGregor, J. Born, and H. L. Fehm, "Overweight humans are resistant to the weightreducing effects of melanocortin4-10," Journal of Clinical Endocrinology and Metabolism, vol. 91, no. 2, pp. 522-525, 2006.

[55] N. J. Underdown, C. R. Hiley, and W. R. Ford, "Anandamide reduces infarct size in rat isolated hearts subjected to ischaemia-reperfusion by a novel cannabinoid mechanism," British Journal of Pharmacology, vol. 146, no. 6, pp. 809-816, 2005. 
[56] K.-V. Chin, "Small molecule intervention for obesity," WO08048636, 2008.

[57] A. Uslu, "Pharmaceutical formulations comprising lipase inhibitor," WO2008082373, 2008.

[58] E. Ravussin, S. R. Smith, J. A. Mitchell et al., "Enhanced weight loss with pramlintide/metreleptin: an integrated neurohormonal approach to obesity pharmacotherapy," Obesity, vol. 17, no. 9, pp. 1736-1743, 2009.

[59] C. Weyer, P. A. Tataranni, S. Snitker, E. Danforth Jr., and E. Ravussin, "Increase in insulin action and fat oxidation after treatment with CL 316,243, a highly selective $\beta 3$ adrenoceptor agonist in humans," Diabetes, vol. 47, no. 10, pp. 1555-1561, 1998.

[60] J. R. S. Arch, "The discovery of drugs for obesity, the metabolic effects of leptin and variable receptor pharmacology: perspectives from $\beta 3$-adrenoceptor agonists," NaunynSchmiedeberg's Archives of Pharmacology, vol. 378, no. 2, pp. 225-240, 2008.

[61] D. P. Bradley, R. Kulstad, and D. A. Schoeller, "Exenatide and weight loss," Nutrition, vol. 26, no. 3, pp. 243-249, 2010.

[62] K. Niswender, "Diabetes and obesity: therapeutic targeting and risk reduction - a complex interplay," Diabetes, Obesity and Metabolism, vol. 12, no. 4, pp. 267-287, 2010.

[63] W. R. Ewing, C. Mapelli, R. B. Sulsky et al., "Human glucagon-like-peptide-1 modulators and their use in treatment of diabetes and related conditions," US20080242593, 2008.

[64] L. Hansen and H. B. Mortensen, "Use of GLP1-Agonists in the treatment of patients with type I diabetes," WO2005023291, 2005.

[65] J. Korner and L. J. Aronne, "Pharmacological approaches to weight reduction: therapeutic targets," Journal of Clinical Endocrinology and Metabolism, vol. 89, no. 6, pp. 2616-2621, 2004.

[66] Z. Li, M. Maglione, W. Tu et al., "Meta-analysis: pharmacologic treatment of obesity," Annals of Internal Medicine, vol. 142, no. 7, pp. 532-546, 2005.

[67] N. T. Bello and M. R. Zahner, "Tesofensine, a monoamine reuptake inhibitor for the treatment of obesity," Current Opinion in Investigational Drugs, vol. 10, no. 10, pp. 11051116, 2009.

[68] R. Padwal, "Contrave, a bupropion and naltrexone combination therapy for the potential treatment of obesity," Current Opinion in Investigational Drugs, vol. 10, no. 10, pp. 11171125, 2009.

[69] F. L. Greenway, K. Fujioka, R. A. Plodkowski et al., "Effect of naltrexone plus bupropion on weight loss in overweight and obese adults (COR-I): a multicentre, randomised, doubleblind, placebo-controlled, phase 3 trial," The Lancet, vol. 376, no. 9741, pp. 595-605, 2010.

[70] H. Bays, "Phentermine, topiramate and their combination for the treatment of adiposopathy ('sick fat') and metabolic disease," Expert Review of Cardiovascular Therapy, vol. 8, no. 12, pp. 1777-1801, 2010.

[71] M. Rinaldi-Carmona, F. Barth, M. Héaulme et al., "Biochemical and pharmacological characterisation of SR141716A, the first potent and selective brain cannabinoid receptor antagonist," Life Sciences, vol. 56, no. 23-24, pp. 1941-1947, 1995.

[72] M. A. M. Carai, G. Colombo, and G. L. Gessa, "Rimonabant: the first therapeutically relevant cannabinoid antagonist," Life Sciences, vol. 77, no. 19, pp. 2339-2350, 2005.
[73] Y. L. Liu, I. P. Connoley, C. A. Wilson, and M. J. Stock, "Effects of the cannabinoid CB1 receptor antagonist SR141716 on oxygen consumption and soleus muscle glucose uptake in Lepob/Lep ob mice," International Journal of Obesity, vol. 29, no. 2, pp. 183-187, 2005.

[74] D. Osei-Hyiaman, M. DePetrillo, P. Pacher et al., "Endocannabinoid activation at hepatic CB1 receptors stimulates fatty acid synthesis and contributes to diet-induced obesity," Journal of Clinical Investigation, vol. 115, no. 5, pp. 12981305, 2005.

[75] D. Cota, G. Marsicano, M. Tschöp et al., "The endogenous cennabinoid system affects energy balance via central orexigenic drive and peripheral lipogenesis," Journal of Clinical Investigation, vol. 112, no. 3, pp. 423-431, 2003.

[76] J.-P. Després, A. Golay, and L. Sjöström, "Effects of rimonabant on metabolic risk factors in overweight patients with dyslipidemia," The New England Journal of Medicine, vol. 353, no. 20, pp. 2121-2134, 2005.

[77] V. Di Marzo and I. Matias, "Endocannabinoid control of food intake and energy balance," Nature Neuroscience, vol. 8, no. 5, pp. 585-589, 2005.

[78] R. Gómez, M. Navarro, B. Ferrer et al., "A peripheral mechanism for CB1 cannabinoid receptor-dependent modulation of feeding," Journal of Neuroscience, vol. 22, no. 21, pp. 96129617, 2002.

[79] M. Gary-Bobo, G. Elachouri, B. Scatton, G. Le Fur, F. OuryDonat, and M. Bensaid, "The cannabinoid CB1 receptor antagonist rimonabant (SR141716) inhibits cell proliferation and increases markers of adipocyte maturation in cultured mouse 3T3 F442A preadipocytes," Molecular Pharmacology, vol. 69, no. 2, pp. 471-478, 2006.

[80] M. R. Helvaci, H. Kaya, A. Borazan, C. Ozer, M. Seyhanli, and A. Yalcin, "Metformin and parameters of physical health," Internal Medicine, vol. 47, no. 8, pp. 697-703, 2008.

[81] C. Addy, P. Rothenberg, S. Li et al., "Multiple-dose pharmacokinetics, pharmacodynamics, and safety of taranabant, a novel selective cannabinoid-1 receptor inverse agonist, in healthy male volunteers," Journal of Clinical Pharmacology, vol. 48, no. 6, pp. 734-744, 2008.

[82] R. Adler, K. B. Landa, M. Manthorpe, and S. Varon, "Cholinergic neuronotrophic factors: intraocular distribution of trophic activity for ciliary neurons," Science, vol. 204, no. 4400, pp. 1434-1436, 1979.

[83] L.-F. H. Lin, D. Mismer, J. D. Lile et al., "Purification, cloning, and expression of ciliary neurotrophic factor (CNTF)," Science, vol. 246, no. 4933, pp. 1023-1025, 1989.

[84] S. Davis, T. H. Aldrich, D. M. Valenzuela et al., "The receptor for ciliary neurotrophic factor," Science, vol. 253, no. 5015, pp. 59-63, 1991.

[85] N. Y. Ip, S. H. Nye, T. G. Boulton et al., "CNTF and LIF act on neuronal cells via shared signaling pathways that involve the IL-6 signal transducing receptor component gp130," Cell, vol. 69, no. 7, pp. 1121-1132, 1992.

[86] M. Sendtner, Y. Arakawa, K. A. Stockli, G. W. Kreutzberg, and H. Thoenen, "Effect of ciliary neurotrophic factor (CNTF) on motoneuron survival," Journal of Cell Science, vol. 100, no. 15, pp. 103-109, 1991.

[87] R. G. Miller, J. H. Petajan, W. W. Bryan et al., "A placebocontrolled trial of recombinant human ciliary neurotrophic (rhCNTF) factor in amyotrophic lateral sclerosis," Annals of Neurology, vol. 39, no. 2, pp. 256-260, 1996. 
[88] W. Pan, A. J. Kastin, L. M. Maness, and J. M. Brennan, "Saturable entry of ciliary neurotrophic factor into brain," Neuroscience Letters, vol. 263, no. 1, pp. 69-71, 1999.

[89] B. Xu, M. G. Dube, P. S. Kalra et al., "Anorectic effects of the cytokine, ciliary neurotropic factor, are mediated by hypothalamic neuropeptide Y: comparison with leptin," Endocrinology, vol. 139, no. 2, pp. 466-473, 1998.

[90] P. D. Lambert, K. D. Anderson, M. W. Sleeman et al., "Ciliary neurotrophic factor activates leptin-like pathways and reduces body fat, without cachexia or rebound weight gain, even in leptin-resistant obesity," Proceedings of the National Academy of Sciences of the United States of America, vol. 98, no. 8, pp. 4652-4657, 2001.

[91] S. Zvonic, P. Cornelius, W. C. Stewart, R. L. Mynatt, and J. M. Stephens, "The regulation and activation of ciliary neurotrophic factor signaling proteins in adipocytes," Journal of Biological Chemistry, vol. 278, no. 4, pp. 2228-2235, 2003.

[92] M. Scott, "Methods for identifyng a candidate for treatment of obesity," WO2006017156, 2006.

[93] B.-A. Bengtsson, S. Eden, L. Lonn et al., "Treatment of adults with growth hormone $(\mathrm{GH})$ deficiency with recombinant human GH," Journal of Clinical Endocrinology and Metabolism, vol. 76, no. 2, pp. 309-317, 1993.

[94] F. M. Ng, J. Sun, L. Sharma, R. Libinaka, W. J. Jiang, and R. Gianello, "Metabolic studies of a synthetic lipolytic domain (AOD9604) of human growth hormone," Hormone Research, vol. 53 , no. 6 , pp. 274-278, 2000.

[95] J. E. Wikberg and F. Mutulis, "Targeting melanocortin receptors: an approach to treat weight disorders and sexual dysfunction," Nature reviews. Drug discovery, vol. 7, no. 4, pp. 307-323, 2008.

[96] L. E. Diamond, D. C. Earle, R. C. Rosen, M. S. Willett, and P. B. Molinoff, "Double-blind, placebo-controlled evaluation of the safety, pharmacokinetic properties and pharmacodynamic effects of intranasal PT-141, a melanocortin receptor agonist, in healthy males and patients with mild-to-moderate erectile dysfunction," International Journal of Impotence Research, vol. 16, no. 1, pp. 51-59, 2004.

[97] J. P. Beck and B. D. Wakefield, "Novel mch receptor antagonists," CN101072775, 2007.

[98] R. A. Houghten, C. Dooley, A. Nefzi, Z. Wang, O. Civelli, and H. Nagasaki, "Melanin-concentrating hormone receptor antagonists and methods of use," US 20080255218, 2008.

[99] D. R. Luthin, "Anti-obesity effects of small molecule melaninconcentrating hormone receptorl (MCHR1) antagonists," Life Sciences, vol. 81, no. 6, pp. 423-440, 2007.

[100] K. A. Anderson, T. J. Ribar, F. Lin et al., "Hypothalamic CaMKK2 contributes to the regulation of energy balance," Cell Metabolism, vol. 7, no. 5, pp. 377-388, 2008. 


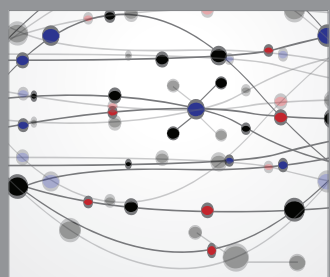

The Scientific World Journal
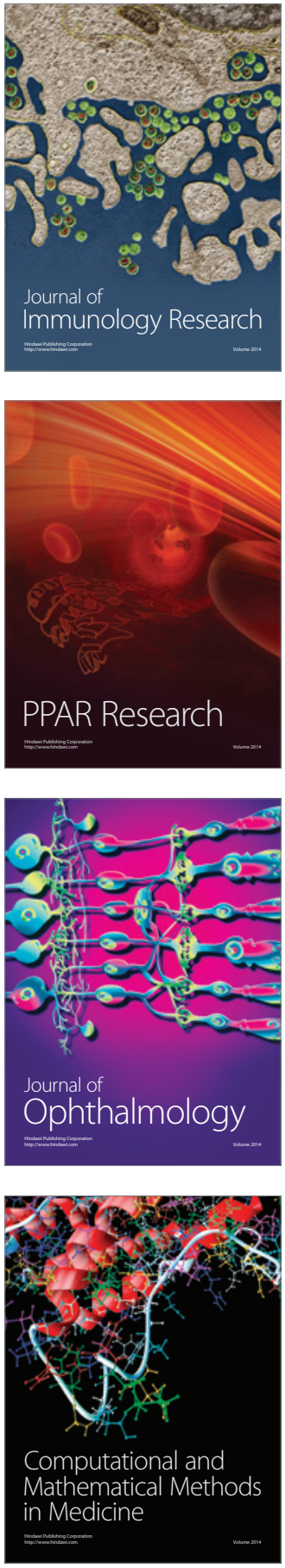

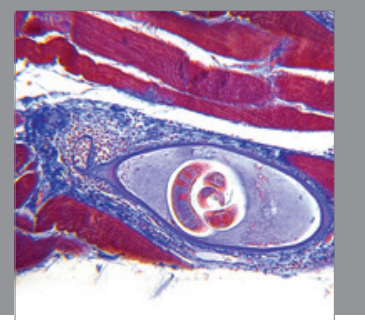

Gastroenterology

Research and Practice
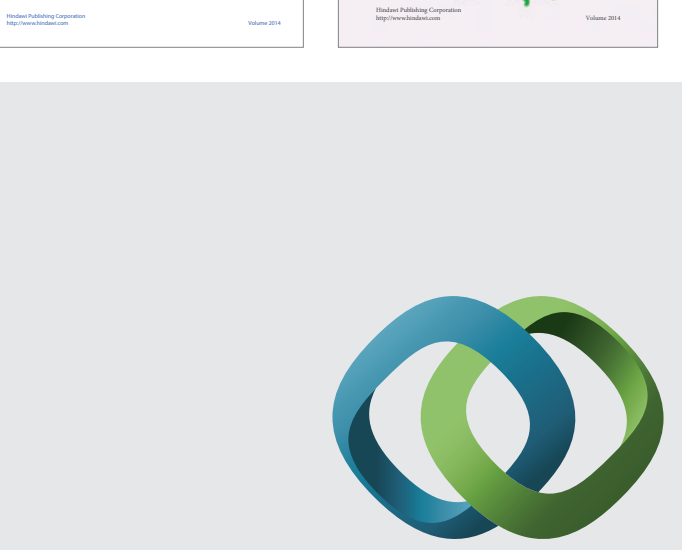

\section{Hindawi}

Submit your manuscripts at

http://www.hindawi.com
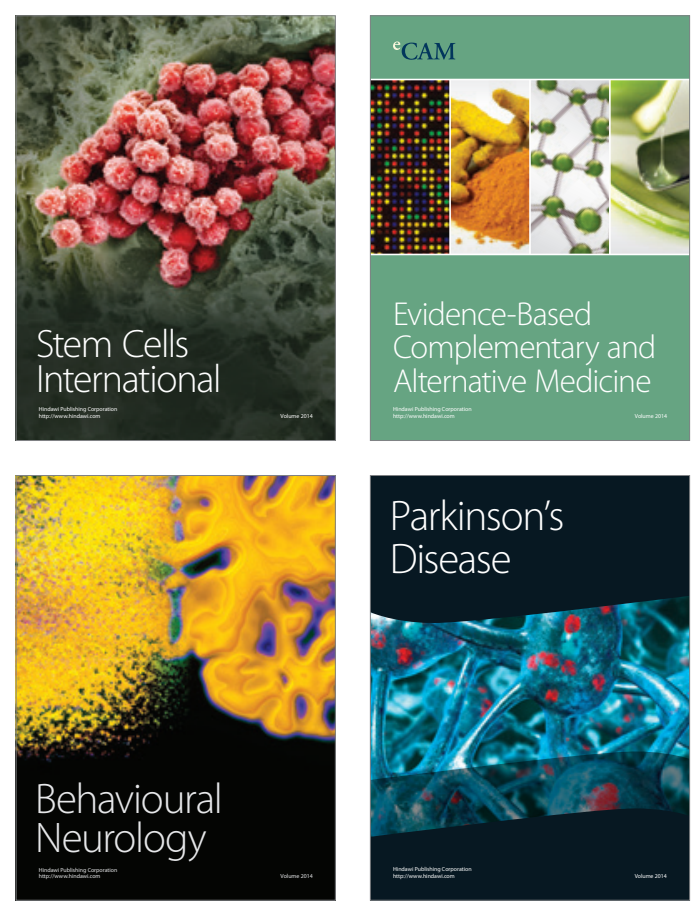

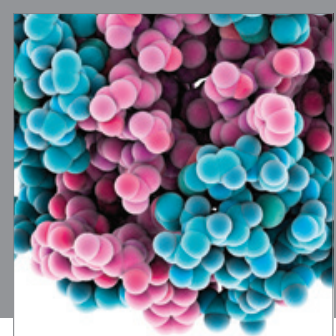

Journal of
Diabetes Research

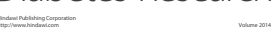

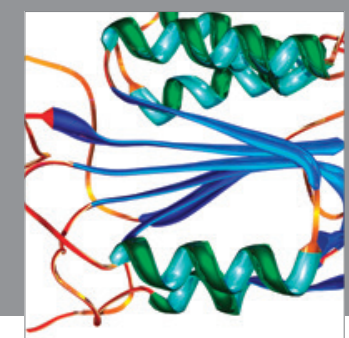

Disease Markers
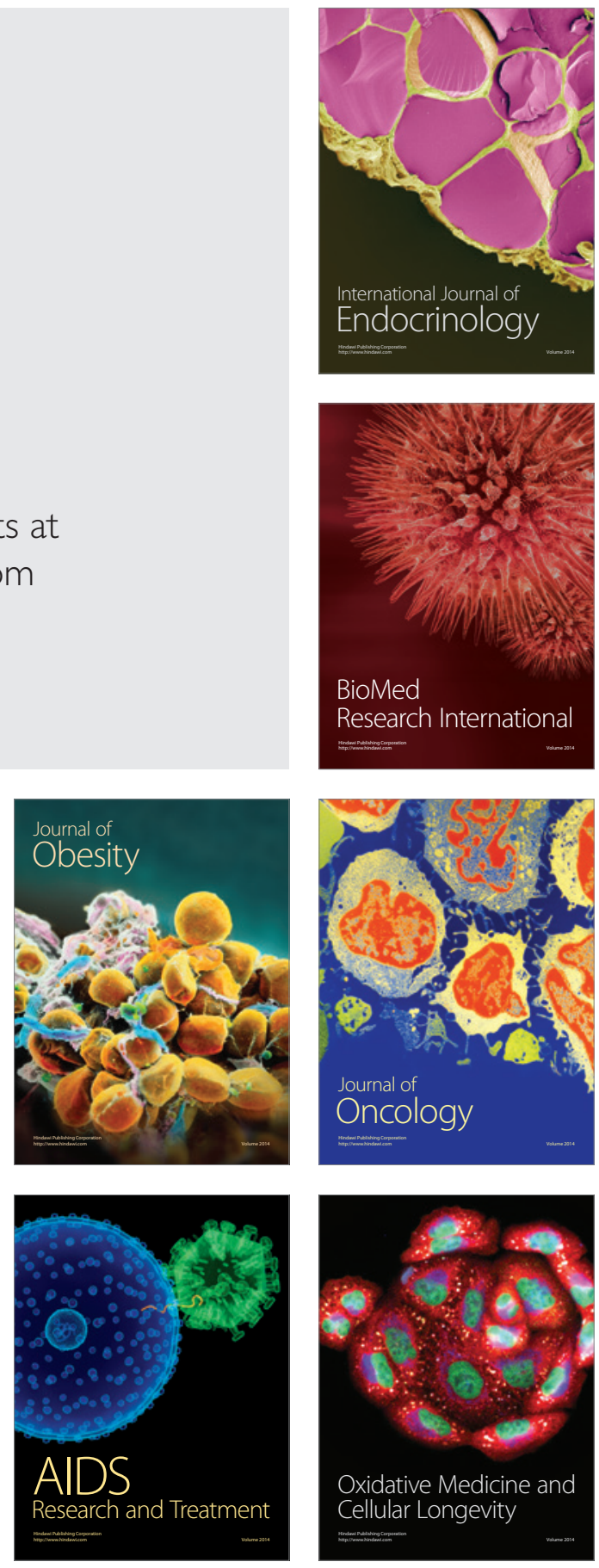